\title{
Geographical distribution and niche conservatism in populations of Orthogeomys dariensis (Rodentia: Geomyidae) in the Chocó Biogeographical region
}

\author{
Juan David Valencia-Mazo ${ }^{1 *}$, Sergio Solari ${ }^{1,2}$ and Andres Arias-Alzate ${ }^{3}$ \\ ${ }^{1}$ Grupo Mastozoología, Universidad de Antioquia. Calle 67 No. 53-108. Medellín, Colombia. Email juandavama@gmail.com (JDVM). \\ ${ }^{2}$ Instituto de Biología, Universidad de Antioquia. Calle 70 No. 52-21, Medellín, AA 1226. Antioquia, Colombia. Email sergio.solari@ \\ udea.edu.co (SS). \\ ${ }^{3}$ Laboratorio de Análisis Espaciales, Instituto de Biología, Universidad Nacional Autónoma de México. Ciudad de México, México. \\ Email andresarias32@gmail.com (AAA). \\ *Corresponding author
}

The Chocó biogeographic region is among the richest in terms of natural resources, species richness and number of endemisms. Among the species endemic to this region, the pocket gopher, Orthogeomys dariensis (Geomyidae), presents a disjunct distribution on both sides of Serranía Darien-Baudó. These populations have been considered as different species, under the names O. dariensis s.s. (northern) and O. thaeleri (southérn). This study aims to model the potential distribution of $O$. dariensis s.s. to assess niche divergence between these geographic populations. Using presence records, associated data, and 19 bioclimatic variables, an ecological niche-modeling approach was applied to: 1) estimate the distribution of the northern and southern populations, both separately and as a single species; 2 ) assess whether each population model predicts the distribution of the other, and analyze their differences through a MESS analysis; and 3) test the overlap and similarity of these niches as a proxy for niche conservatism between $O$. dariensis s.S. and O. thaeleri, through the estimation of ecological niche ellipsoids for the fundamental niche $\left(E_{A}\right)$. When considered as separate populations, these show an allopatric distribution, with the Darién-Baudó zone acting as a barrier between them. Also, $O$. dariensis data predicts a large part of the distribution of $O$. thaeleri over the study region, and vice versa. When considered as a single species, it shows a broader and continuous range, including the Darién-Baudó region as part of its potential distribution. The MESS analysis shows similar climatic conditions in general, and few particular conditions that are unique to each zone, which would not represent conditions so unique as to segregate them. Therefore, the apparent disjunction between populations may be due to the lack of records and systematic surveys in this region. This is also reflected in the moderate overlap of their niche ellipsoids, showing the ecological conditions shared between these populations. Our results support the existence of a single species, O. dariensis (sensu Hafner 2015), with a broad and continuous distribution in the Chocó biogeographic region. This is consistent with recent analyzes of DNA data showing very low genetic divergence between populations north and south of Darién-Baudó (as an intermediate area). Rather than a barrier promoting diversification, this region could represent a dispersal area for these populations.

La región del Chocó Biogeográfico es una de las zonas del mundo con mayor riqueza en recursos naturales, diversidad y endemismo de especies. Entre las especies endémicas de la región se encuentra la tuza Orthogeomys dariensis (familia Geomyidae), que presenta una distribución discontinua a ambos lados de la zona Darién-Baudó. Esquemas taxonómicos previos consideraban estas poblaciones disyuntas como especies distintas; O. dariensis s.s. al norte y O. thaeleri al sur. En este estudio se modela la distribución potencial de O. dariensis s.s. y evalúa la diferenciación de nicho de dichas poblaciones. Usando registros de presencia, información asociada, y 19 variables bioclimáticas, 1) se estimaron las distribuciones potenciales para las poblaciones norte y sur y como especie; 2) se evaluó si cada modelo poblacional predice la distribución del otro y mediante el análisis de similitud multivariada ambiental (MESS) se evaluó qué tan diferentes climáticamente son estas áreas con respecto a la de cada grupo; y 3) se realizó una prueba de similitud de nicho ecológico como 'proxy' del conservadurismo de nicho entre O. dariensis s.S. y O. thaeleri mediante la estimación de los elipsoides del nicho fundamental existente $\left(\mathrm{E}_{\mathrm{A}}\right)$ en el espacio ecológico. Considerados como poblaciones independientes, estas presentan una distribución alopátrica, con el Darién-Baudó como una barrera entre ellas. Asimismo, O. dariensis predice gran parte de la distribución de $O$. thaeleri sobre las áreas evaluadas, y viceversa. Consideradas como una sola especie, ésta presenta una distribución potencial mucho más amplia y continua, incluyendo la zona del Darién-Baudó. El análisis MESS muestra condiciones climáticas similares y algunas particulares entre cada zona evaluada, pero que no representarían condiciones únicas como para separarlas significativamente. Siendo así, esta alopatría podría ser un artificio metodológico por falta de registros y muestreos sistemáticos en la zona. Esto también se refleja en la sobreposición media de sus elipsoides del nicho ecológico, donde estas poblaciones comparten condiciones ecológicas. Nuestros resultados señalan la presencia de una única especie O. dariensis (sensu Hafner 2015) con una distribución amplia y continua en el Chocó Biogeográfico. Esto es congruente con análisis previos de secuencias de ADN que indican baja o nula divergencia entre poblaciones al norte y sur de la zona Darién-Baudó (área intermedia); ésta, más que una barrera, representaría una potencial zona de dispersión de ambas poblaciones.

Key words: Biogeographic Chocó, niche conservatism, potential distribution, Geomyidae, pocket gophers.

@ 2017 Asociación Mexicana de Mastozoología, www.mastozoologiamexicana.org

\section{INTRODUCTION}

The Chocó biogeographic region, stretching from southern Panama to northern Ecuador, is one of the regions of greater richness and biological uniqueness worldwide (Hernández-Camacho et al. 1992; Morrone 2001), covering the western (Pacific) slope of the Andes, from sea level to 
2,000 m (sensu Gentry 1982; Olson and Dinerstein 2002). This biological uniqueness is due to the presence of ecosystems as varied as the Chocó trans-Andean rainforests, the Chocó-Darien humid forests, the montane humid forests of Panama and the Chocó-Esmeraldas mangroves (Holdridge et al. 1971; Hershkovitz 1982; Hernández-Camacho et al. 1992; Arias-Alzate et al. 2012). These ecosystems, communicated with the inter-Andean valleys of the northern end of the Western and Central Cordilleras, are dispersal routes for lineages originated in South, North and Central America (Hernández-Camacho et al. 1992; Morrone 2001). Therefore, the Chocó is a region of great importance for understanding the systematics and historical biogeography of many vertebrate species (Morrone 2001; Arias-Alzate et al. 2012).

A total of 84 rodent species are currently recorded for the Chocó biogeographic region (Méndez 1993; Tirira 2010; Solari et al. 2013), many of which display a continuous distribution throughout the region. Groups like the genus Orthogeomys, although showing high diversity from southern Mexico to Central America, have a low species richness in the north tip of South America (Goldman 1920; Hall and Kelson 1959; Méndez 1993). In this region, Serranía del Darién, Serranía de los Saltos and Serrania del Baudó form a mountain range that apparently function as a geographical barrier restraining the dispersal of the terrestrial fauna toward southern areas (Alberico 1990; Sudman and Hafner 1992; Valdés-Velásquez 2003; Hafner 2015). However, some authors argue that in the case of fossorial species this mountain range does not represent a definitive biogeographical barrier (Alberico 1990; Monge 2010).

Historically, the presence of $O$. dariensis in the region had been reported in several locations in the eastern end of Panama, near Serranía del Darién between 80 and 750 $\mathrm{m}$ on the border with Colombia (Goldman 1920; Handley 1966). For its part, O. thaeleri was described by Alberico (1990) and is known from several localities across central Chocó between 30 and $100 \mathrm{~m}$. Until now, these populations had been treated as different species based on differences in pelage and cranial features (Alberico 1990). However, due to the low genetic divergence between individuals assigned to both species, $0.3 \%$ for the cytochrome-b mitochondrial gene (Sudman and Hafner 1992) and $0 \%$ for two nuclear genes (Spradling et al. 2016), O. dariensis and $O$. thaeleri are currently considered as a single species (Hafner 2015; Spradling et al. 2016).

Given the few distributional and ecological studies on these populations (Goldman 1920; Alberico 1990; Correa and Perea 2007), their geographical ranges remain little known. Moreover, the spatial and temporal variability of their niches, which would allow an approximation to the evolutionary history of the species, remain are unknown. In this investigation, stemming from the hypothesis that $O$. dariensis s.s. and O. thaeleri are two allopatric populations, we evaluated the degree of ecological segregation between these populations through an approximation of ecological niche models and niche conservatism hypotheses.

\section{METHODOLOGY}

Species records. Records of the presence of O. dariensis (northern and southern populations) were gathered through a revision of the specimens deposited in biological collections of Universidad Tecnológica de Chocó (Quibdó) and Instituto Alexander von Humboldt (Villa de Leyva); in addition, the relevant information in the scientific literature was reviewed (e. g., Alberico 1990; Reid 2009; Hafner 2015). For each record, the data gathered included locality and geographical coordinates (in decimal degrees), height above sea level and source of the records. The characteristics of soil were described according to the Soil Geographic Databases compendium (www.soilgrids.org).

Climate Information. Given the scarce knowledge on the taxonomy, ecology and distribution of these taxa (Goldman 1920; Alberico 1990; Correa and Perea 2007), and to avoid subjectivities in the selection of the most relevant climate variables that determine the distribution of $O$. dariensis, 19 bioclimatic variables were used from the general circulation model CGCM31 developed by CCMA (Canadian Center for Climate Modeling and Analysis), downloaded from the WorldClim webpage (http://www.worldclim.org, Hijmans et al. 2005). All variables were processed with a resolution of 30 arc-seconds (equivalent to $1 \mathrm{~km}^{2}$ or 0.008333 degrees).

Ecological niche models and potential distribution. Numerous methods for the study of ecological niches and geographic distributions are currently available, which have been compared extensively (Elith and Graham 2009; Elith et al. 2011; Peterson et al. 2011). For this reason, since our objective focuses mainly on ecological and evolutionary aspects of isolated populations rather than on the comparison of these methods, this study was conducted using the MaxEnt algorithm, a heuristic method that has produced satisfactory results (Elith et al. 2011; Santika 2011). The ecological niche modeling with MaxEnt estimates the probability of occurrence of a species through space, by comparing the ecological conditions in which the species has been recorded vs. a sample of background pixels of the study area using a Bayesian adjustment procedure and under the maximum-entropy principle (Phillips et al. 2006; Phillips and Dudik 2008). The predictions derived represent hypotheses on conditions similar to those where the species has been observed; the result is often interpreted as the potential distribution of the species (sensu Peterson et al. 2011).

From the hypothesis that $O$. dariensis has two populations (corresponding to $O$. dariensis s. s. and O. thaeleri as defined by Alberico 1990), two strategies were developed to model the potential distribution ranges. In the first strategy, the geographic distributions are estimated and compared considering two separate populations; in the second strategy, the species is modeled as a single taxon (O. dariensis s.l.). These distributions were derived by dividing the total number of records $\left(G_{+}\right.$, sensu Peterson et al. 2011) in two data sets: a calibration data set (75\% of the data) and 
an evaluation data set $(25 \%)$, the procedure was repeated 100 times (100 replicates, each with 500 iterations; and each data set with different random partitions) using the bootstrap method (Phillips et al. 2006; Phillips and Dudik 2008).

As little is known about the ecological features and dispersal ability of this species, two areas ( $M$; sensu Peterson et al. 2011) of different size (small and large) were produced to explore whether each individual population considered separately predicted the distribution of the other. Given the geographical characteristics of the region between Panama and Colombia, areas of 4,560 km² and 25,500 km were generated for the northern population; and areas of $5,700 \mathrm{~km}^{2}$ and $24,800 \mathrm{~km}^{2}$, for the southern population. In addition, an analysis of multivariate environmental similarity surfaces (MESS; Elith et al. 2011; Saupe et al. 2012) explored the extent of the climatic differences between these areas, and whether some variables show values outside of the calibration area (the area where the model was produced) that might be influencing predictions (area where the model was projected) to a significant extent. The fitness, performance and discriminating capacity of the models were evaluated through the ROC (Receiver Operating Characteristic) curve and the AUC (Area Under the ROC curve) value, based on validation data (Phillips et al. 2006; Muscarella et al. 2014). The AUC TEST $_{\text {has }}$ hroved to be a useful tool for ordinal scoring models (McPherson 2004; Thuiller et al. 2005; Santika 2011; Muscarella et al. 2014). The key variables for each population were identified using the Jacknife test (incorporated in MaxEnt).

Subsequently, a climatic characterization of the distributions in terms of temperature and precipitation was carried out for the analysis of the potential climatic segregation between populations, which would effectively validate a bias in terms of the geographical representativeness of populations. These variables have shown a good environmental resolution to interpret the interactions between species and their environment (abiotic factors) (see $\underline{\text { Tocchio }}$ et al. 2015; Qiao et al. 2016). Likewise, this characterization was performed for the Darién-Baudó, the geographic area in between the two separate distributions (see results), which apparently would function as a geographical barrier restraining the dispersal of these and other populations to southern areas in the region (Alberico 1990; Sudman and Hafner 1992; Valdés-Velásquez 2003; Hafner 2015). All subsequent processing and analyses were carried out in a geographic information system using the software ArcGIS 10.1 (ESRI 2014).

Similarity and conservatism of ecological niches. After exploring and estimating the distribution range for each population separately and for the two populations combined, we conducted an ecological niche similarity test as a proxy for niche conservatism (Wiens and Graham 2005). To this end, both the individual ellipsoids of each separate population and the one of the overall species were estimated in the ecological space using probabilistic models (MaxEnt output) as the hypothesis of the existing funda- mental niche $\left(\mathrm{E}_{\mathrm{A}}\right)$ (Soberon and Nakamura 2009; Peterson et al. 2011; Qiao et al. 2016). This was conducted by means of the similarity and ecological niche overlap algorithm using the program Niche Analyst (NicheA; Qiao et al. 2016). Given the difficulty to estimate and visualize the multi-dimensional ecological space and the subsequent representation of niches in such space, a principal components analysis (PCA) was performed with climatic variables to reduce the dimensionality and hence visualize the ecological space in three dimensions (three principal components, $X, Y, Z$ ), in order to depict the ellipsoids. This overlapping analysis was used to calculate the volume of the ellipsoids corresponding to the three ecological niches, with their respective centroids, eigenvectors and percentage of shared volume. The similarity between ecological niches was measured with the Jaccard index, which produces values between 0 and 1 , indicating the degree of similarity between niches in the ecological space (Qiao et al. 2016).

\section{RESULTS}

Ecological niche models and potential distribution. A total of 15 records of the species were recorded, six for the northern population (O. dariensis S.s.) and nine for the southern population ( $O$. thaeleri), following the nomenclature proposed by Alberico (1990; Table 1). Both estimates of the distributions showed good performance and discriminating capacity $\left(A \cup C_{\text {TEST }}=0.995 \pm 0.005\right)$. The variables identified as most important for the two groups were precipitation in the coldest trimester, temperature seasonality, and temperature in the coldest month.

Considering both populations separately, geographical distributions are allopatric and associated with very humid forests with high precipitation and low temperature seasonality, being separated by the Darién-Baudó zone, which appears as an area that delimits the two distributions (Fig-

Table 1. Geographic records of $O$. dariensis and its populations in the Chocó biogeographic region.

\begin{tabular}{|c|c|c|c|c|c|}
\hline Taxon & Country & $\begin{array}{l}\text { Department/ } \\
\text { Province }\end{array}$ & Locality & Length & Latitude \\
\hline \multirow{9}{*}{$\begin{array}{l}\text { Southern } \\
\text { population } \\
\text { (Orthogeomys } \\
\text { thaeleri) }\end{array}$} & Colombia & Chocó & Alto Baudó & -77.3500 & 6.0000 \\
\hline & Colombia & Chocó & Nuquí & -77.2410 & 5.7120 \\
\hline & Colombia & Chocó & $\begin{array}{l}\text { Bahía } \\
\text { Solano }\end{array}$ & -77.3370 & 5.9970 \\
\hline & Colombia & Chocó & $\begin{array}{l}\text { Bahía } \\
\text { Solano }\end{array}$ & -77.0830 & 6.0000 \\
\hline & Colombia & Chocó & Bajo Baudó & -77.0500 & 5.0500 \\
\hline & Colombia & Chocó & Bajo Baudó & -77.0500 & 5.0501 \\
\hline & Colombia & Chocó & Bajo Baudó & -77.0500 & 5.0502 \\
\hline & Colombia & Chocó & Juradó & -77.5710 & 7.1110 \\
\hline & Colombia & Chocó & Nuquí & -77.2333 & 5.7667 \\
\hline \multirow{6}{*}{$\begin{array}{l}\text { Northern } \\
\text { population } \\
\text { (Orthogeomys } \\
\text { dariensis s.s.) }\end{array}$} & Panama & Darién & $\mathrm{N} / \mathrm{A}$ & -78.0989 & 8.3278 \\
\hline & Panama & Darién & $\mathrm{N} / \mathrm{A}$ & -77.7550 & 7.8540 \\
\hline & Panama & Darién & N/A & -77.6860 & 7.7790 \\
\hline & Panama & Darién & N/A & -77.7730 & 7.9270 \\
\hline & Panama & Darién & $\mathrm{N} / \mathrm{A}$ & -77.7170 & 7.9170 \\
\hline & Panama & Darien & $\mathrm{N} / \mathrm{A}$ & -77.7550 & 7.8550 \\
\hline
\end{tabular}


ure 1). The approximate distribution of the northern population includes the far south of Panama, mainly in the Province of Darién, which shows heavily leached red and yellow soils, with accumulation of clay, low cation-exchange capacity and low base saturation, stretching up to the northern portion of Serranía del Baudó and the alluvial valleys of Atrato and San Juan rivers, in Colombia. The distribution of the southern population is restricted to lowlands and soft non-alluvial soils in south-central Serranía del Baudó and the southern portion of the alluvial valleys of Atrato and San Juan rivers, from 0 up to $100 \mathrm{~m}$, in the Pacific region of Colombia (Figure 1). For its part, when considered as a single species, it shows a continuous distribution range across an area of approximately $117,233 \mathrm{~km}^{2}$, and the DariénBaudó zone is no longer displayed as a splitting area (Figure 1). However, although favorable conditions for the potential distribution of $O$. dariensis occur to the Pacific coastal plains, its southern distribution limit is possibly the San Juan river, which becomes a barrier for the species (Figure 1).

Considering the areas evaluated, both the small and the large area (for each species), the northern population predicts to a large extent the distribution of the southern population, and vice versa (Figure 2). On the other hand, the MESS analysis and the environmental variables associated with each area show that, although these areas share similar climatic conditions, there are some particular envi-

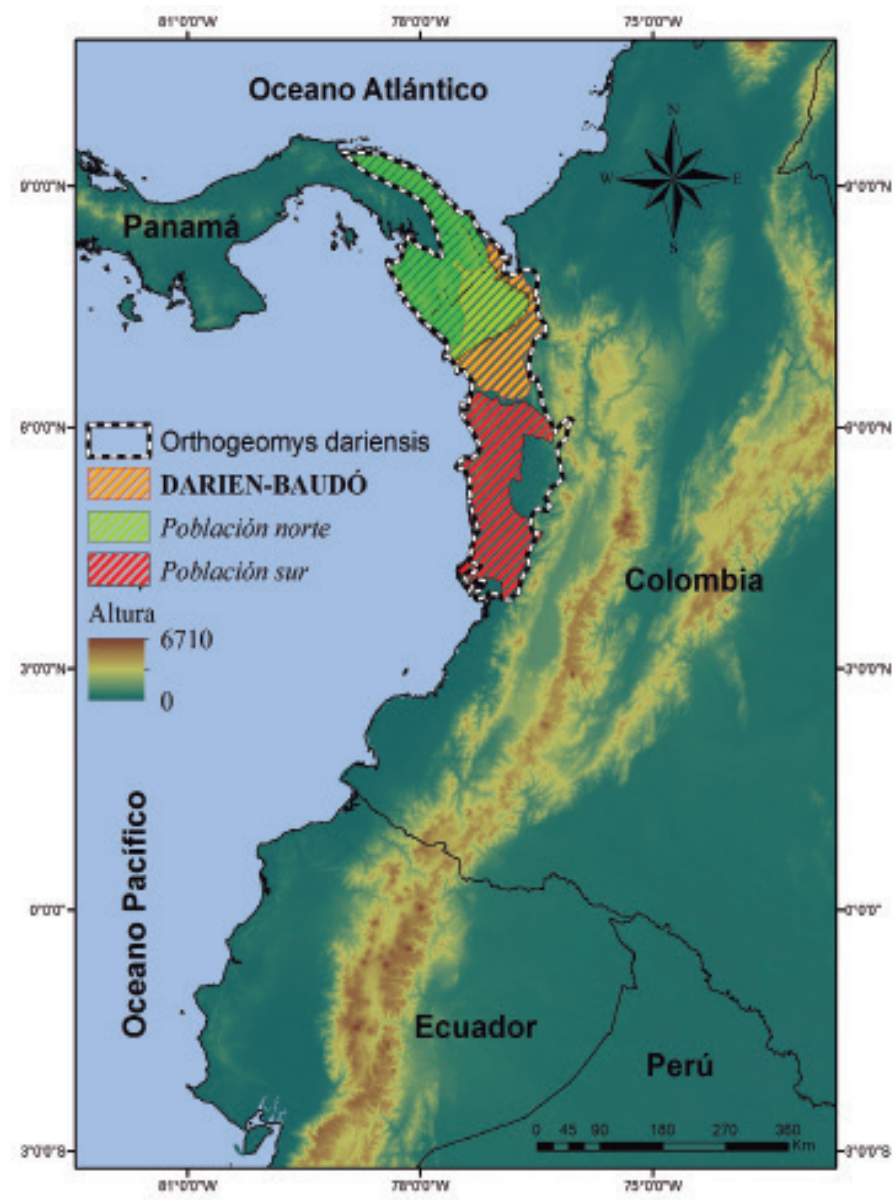

Figure 1. Study area and potential distributions of the northern population (green), southern population (red), and O. dariensis (dotted line) in the Chocó biogeographic region. ronmental characteristics $(P<0.05)$, which apparently do not represent conditions so unique as to separate these populations to any significant extent (Figure 3).

Similarity and conservatism of the ecological niche.

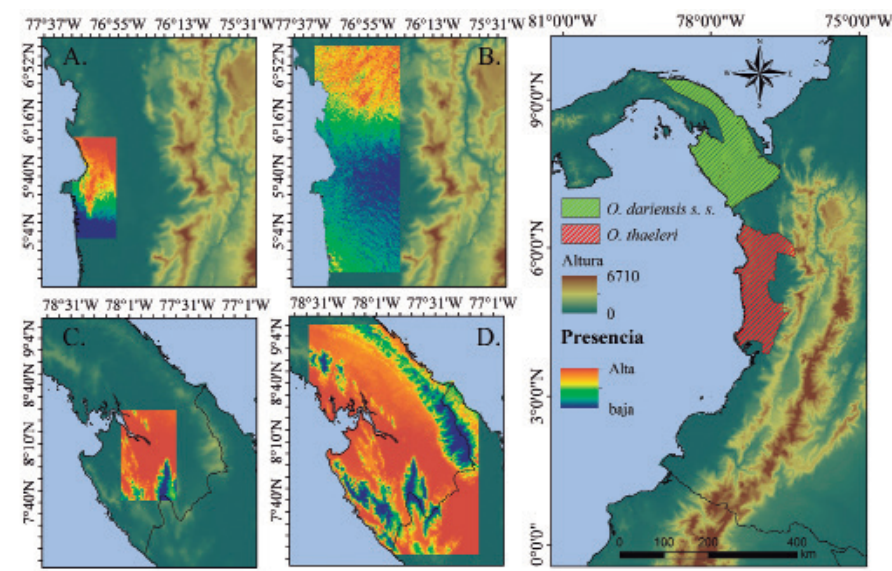

Figure 2. Potential distribution and predictions of the two populations of Orthogeomys dariensis in the Chocó biogeographic region. Prediction of the presence (A. small area; $\mathbf{B}$. large area) of the northern population based on the southern population. Prediction of the presence (C. small area; $\mathbf{D}$. large area) of the southern population based on the northern population. Note the Darien-Baudo zone as a potential barrier when two allopatric populations are considered.

According to the niche similarity analysis in the ecological space, both populations show a slight overlap of their ellipsoids (Jaccard index $=0.30$; Figure 4). However, these hyper-volumes are subdivisions of a much larger niche when a single species with a continuous distribution area is considered (Figure 4). In this way, more than niche conservatism or divergence between the two populations, these findings reflect the ecological and environmental conditions associated with each population, one to the north and the other in a location closer to the center of the Chocó biogeographic region.

\section{DISCUSSION}

Among the various groups of small non-flying mammals that colonized South America during the Great American Biotic Exchange after the establishment of the Panamanian Bridge (Marshall et al. 1982; Cody et al. 2010; Almendra and Rogers 2012), apparently the least successful, as evidenced by their limited dispersal in South America (Simpson 1950), are shrews (Woodman and Pefaur 2008) and pocket mice of the genus Heteromys (Anderson 2000). However, for fossorial species belonging to the family Geomyidae, this dispersal was seemingly even more restricted, having inhabited and undergone diversification mainly in Central America.

In this region, O. dariensis (sensu Hafner 2015) shows two allopatric populations, with a southern range reaching the San Juan river $\left(4.20^{\circ}\right.$ North latitude). These is consistent with the genetic analyses by Spradling et al. (2016), which show a very low genetic divergence in mitochondrial and nuclear DNA between these populations (Spradling et al. 2016). This is also supported by the morphometric analyses of Hafner (2015) and Spradling et al. (2016), who suggest that the morphological variability between the Colombian 


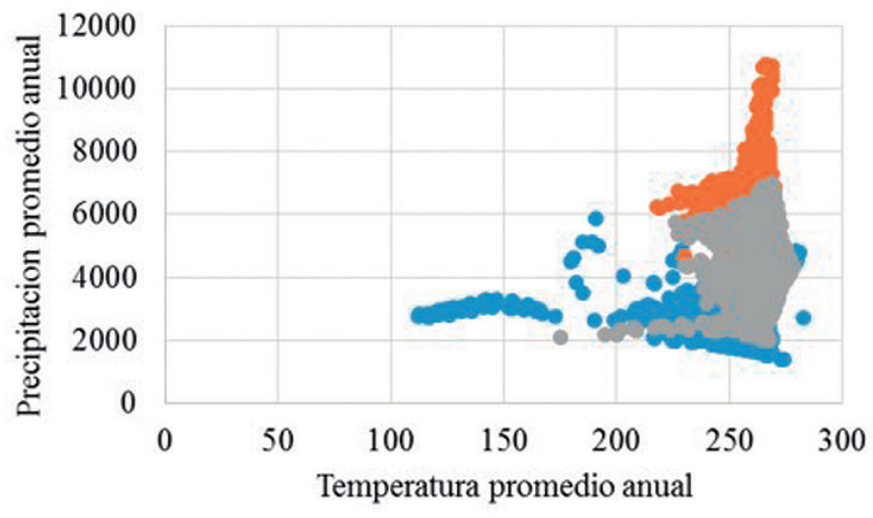

- Población norte Población sur • DARIEN-BAUDÓ
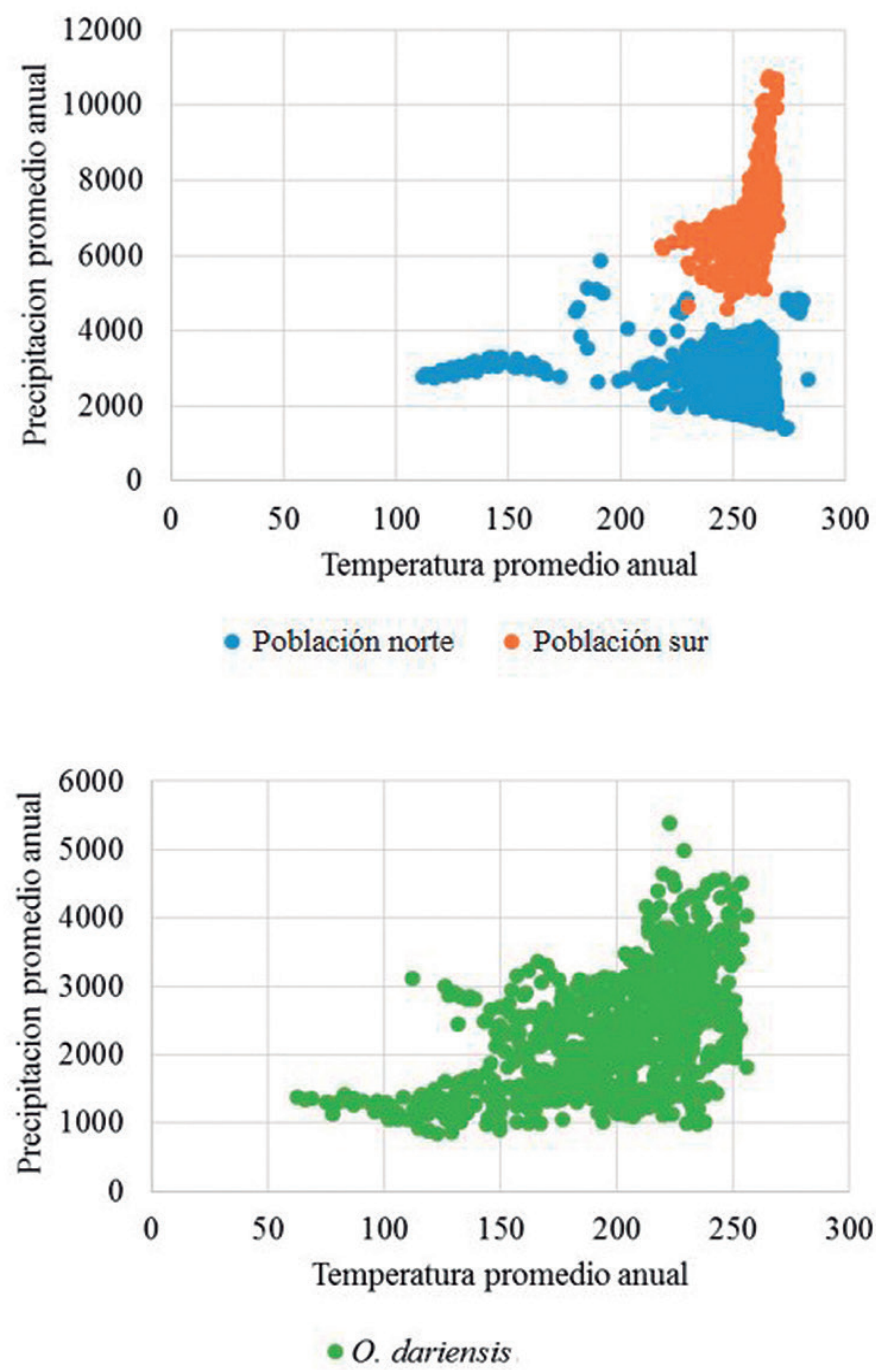

Figure 3. Climate analysis of the distributions of the northern population (blue), southern population (orange), the Darién-Baudo intermediate zone (gray), and 0 . dariensis as a single species (green) in the Chocó biogeographic region.

and Panamanian populations is insufficient to consider them as different species.

Likewise, the slight overlap of the ecological niches of the two populations reflects the particular ecological conditions in the areas they inhabit. Rather than considering the Darién-Baudó zone as a barrier restraining the disper- sal and promoting the diversification for these gophers (Alberico 1990; Sudman and Hafner 1992; Valdés-Velásquez $\underline{2003}$ ), it may represent an area that connects both populations. Furthermore, Correa and Perea (2007) and Alberico (1990) point out that the burrow systems of populations in the Colombian Chocó are built in "inorganic clay" soils, with low-to-medium plasticity, and with scarcely developed profiles due to the continuing input of sediments from the Torreidó river; these characteristics are similar to those found in the Darién-Baudó intermediate zone (mainly in Medio Baudó, Chocó), which would facilitate the mobility and dispersal of populations in the region.

In order to gain a more comprehensive understanding

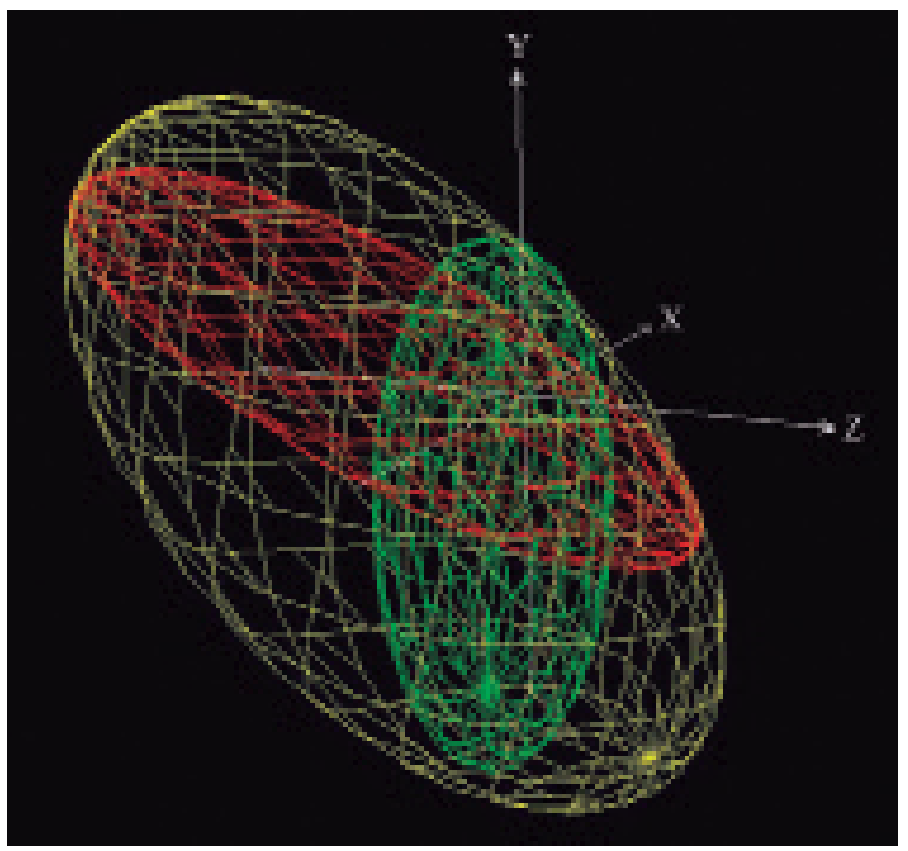

Figure 4. Ecological niches in the ecological space of the northern population (green), southern population (red), and Orthogeomys dariensis as a single species (yellow) in the Chocó biogeographic region.

of the evolutionary history and distribution of this geomyid species in the Chocó region, further studies are needed to confirm the presence and gather additional records, mainly for the Darién-Baudó zone, where no records are currently available. However, we believe that the species might be present based on its physical and environmental characteristics (see above). Such studies would contribute to a better understanding of the role of the Darién-Baudó (with an extension of $50 \mathrm{~km}$ wide approximately) as a dispersal route for populations of South and Central America. These responses are key to understand geographical and ecological differentiation patterns, not only regarding $O$. dariensis, but also with respect to the biotic and abiotic processes that have taken place in the region.

\section{ACKNOWLEDGMENTS}

We are grateful to each of the institutions and the persons in charge of collections, for their hosting and collaboration in the revision of the specimens studied here: Alex Mauricio Jimenez of Universidad Tecnología del Chocó and Claudia 
Medina of Instituto de Investigación de Recursos Biológicos Alexander von Humboldt, Villa de Leyva. To the reviewers and associate editor, for their comments and suggestions, which helped to significantly improve the manuscript. Thanks also to the colleagues of the Mammalogy Group at University of Antioquia in Medellín, for their comments and assistance in data processing, and in particular to Octavio Rojas (INECOL, Mexico) for his suggestions to improve the manuscript. María Elena Sánchez-Salazar translated the manuscript to English.

\section{LITERATURE CITED}

Alberico, M. 1990. A new species of pocket gopher (Rodentia: Geomyidae) from South America and its biogeographic significance. Pp: 103-111 in Vertebrates in the Tropics: Proceedings of the International Symposium on Vertebrate Biogeography and Systematics in the Tropics (Peters G., and R. Hutterer, edit.). Bonn, June 5-8, 1989. Alexander Koenig Zoological Research Institute and Zoological Museum, Bonn, Germany.

Almendra, A. L., AND D. S. Rogers. 2012. Biogeography of Central American mammals. Patterns and processes. Pp. 203-228, in Bones, Clones and Biomes. The History and Geography of Recent Neotropical Mammals (Patterson, B. D., and L. P. Costa, edit.). The University of Chicago Press. Chicago, U. S. A.

ANDERSON, R. P. 2000. Preliminary review of the systematic and biogeography of the spiny pocket mice (Heteromys) of Colombia. Revista de la Academia Colombiana de Ciencias Exactas, Físicas y Naturales, 23 (Suplemento especial): 611630.

Arias-Alzate, A., J. F. González-Maya, and L. R. Víquez. 2012. Conservación de mamíferos del Chocó: distribución, riqueza y representatividad de las áreas protegidas. Revista Biodiversidad Neotropical 2:71-82.

Cody, S., J. E. Richardson, V. Rull, C. Ellis, and R. T. Pennington. 2010. The great American biotic interchange revisited. Ecography 33:326-332.

Correa, A., And T. Perea. 2007. Taxonomía y algunos aspectos ecológicos del género Orthogeomys (Covatierra) y su incidencia en cultivos agrícolas en el municipio del medio Baudó (Chocó). Facultad de Ciencias Básicas. Programa de Biología con énfasis en recursos naturales. Universidad Tecnológica del Chocó.

ELITH, J., AND C. H. GRAham. 2009. Do they? How do they? WHY do they differ? On finding reasons for differing performances of species distribution models. Ecography 32:66-77

Elith, J., S. J. Phillips, T. Hastie, M. Dudí, Y. E. Chee, and C. J. Yates. 2011. A statistical explanation of MaxEnt for ecologists. Diversity and Distributions 17:43-57.

Environmental Systems Research Institute (ESRI). 2014. ArcGIS 10.1. Environmental Systems Research Institute. Redlands, U. S. A. GentRY, A. H. 1982. Phytogeographic patterns as evidence for a Chocó refuge. Pp. 112-136, in Biological Diversification in the Tropics (Prance, G. T., ed.). Columbia University Press. New York, U. S. A.

Goldman, E. A. 1920. Mammals of Panama. Smithsonian Miscellaneous Collections 69:1-309.

HAfNeR, M. S. 2015. Family Geomyidae Bonaparte, 1845. Pp.
49-51, in Mammals of South America, volume 2 - Rodents (Patton, J. L., U. F. J. Pardiñas, and G. D'Elía, edit.). The University of Chicago Press. Chicago, U. S. A.

HaLL, E. R., AND K. R. KELSON. 1959. The mammals of North America. Vol. 1. Ronald Press. New York, U. S. A.

HANDLEY, C. O., JR. 1966. Checklist of the mammals of Panama. Pp. 753-795, in Ectoparasites of Panama (Wenzel, R. L., and V. J. Tipton, edit.). Field Museum of Natural History. Chicago, U. S. A. Hernández-Camacho J. I., A. Hurtado Guerra, R. Ortiz Quijano, and T. WALSCHBURGER. 1992. Unidades biogeográficas de Colombia. Acta Zoológica Mexicana, (volumen especial): 105-151.

HERSHKOVITZ P. 1982. The recent mammals of the Neotropical region: a zoogeographic and ecological review. Pp. 311-431, ni Evolution, mammals and Southern Continents (Keast, A., F. C. Erk, and B. Glass, edit.). State University of New York Press. Albany, New York, U. S. A.

Hijmans, R. J., S. E. Cameron, J. L. Parra, P. G. Jones, and A. Jarvis. 2005. Very high resolution interpolated climate surfaces for global land areas. International Journal of Climatology 25: 1965-1978.

Holdridge, L. R., W. Grenke, W. H. Hatheway, T. Liang, and J. A. Tosi. 1971. Forest Environments in Tropical Life Zones: a pilot study. Pergamon Press. Oxford, U. K.

Marshall, L. G., S. D. WebB, J. J. Sepkoski, and D. M. Raup. 1982. Mammalian evolution and the Great American Interchange. Science 215:1351-1357.

McPherson, J. 2004. The effects of species' range sizes on the accuracy of distribution models: ecological phenomenon or statistical artefact? Journal of Applied Ecology 41:811-823.

Méndez, E. 1993. Los roedores de Panamá. Publicado independientemente por el autor. Panamá. xii + 372 pp.

MonGE, J. 2010. Distribución geográfica, características y clave taxonómica de las taltuzas (Orthogeomys spp. Rodentia: Geomyidae) en Costa Rica. Cuadernos de Investigación UNED 2:23-31.

Morrone J. J. 2001. Biogeografía de América Latina y el Caribe. Manuales y Tesis, volumen 3. Zaragoza, España.

Muscarella, R., P. J. Galante, M. Soley-Guardia, R. A. Boria, J. M. Kass, M. URIARTE, AND R. P. ANDERSON. 2014. ENMeval: An R package for conducting spatially independent evaluations and estimating optimal model complexity for Maxent ecological niche models. Methods in Ecology and Evolution 5:1198-1205.

Olson, D. M., AND E. DINERSTEIN. 2002. The Global 200: priority ecoregions for global conservation. Annals of the Missouri Botanical Garden 89:199-224.

Peterson, A. T., J. Soberon, R. G. Pearson, R. P. Anderson, E. MartínezMeyer, M. Nakamura, and M. B. Araujo. 2011. Ecological niches and geographic distributions. Monographies in Population Biology, 49. Princeton University Press. Princeton, U. S. A.

Phillips, S. J., R. P. Anderson, and R. E. SchapiRe. 2006. Maximum entropy modeling of species geographic distributions. Ecological Modeling 190:231-259.

PhILLIPS, S. J. AnD M. Dudík. 2008. Modeling of species distributions with MaxEnt: New extensions and a comprehensive evaluation. Ecography 31:161-175.

Qiao, H., A. T. Peterson, L. P. Campbell, J. Soberon, L. Jl, AND L. E. Escobar. 2016. NicheA: creating virtual species and ecological niche in multivariante environmental scenarios. Ecography 39:805-813.

REID, F. A. 2009. A field guide to the mammals of Central 
America and southeast Mexico. 2nd ed. Oxford University Press. New York and Oxford, U. S. A. and United Kindom.

SANTIKA, T. 2011. Assessing the effect of prevalence on the predictive performance of species distribution models using simulated data. Global Ecology and Biogeography 20:181-192.

Saupe, E. E., V. Barve, C. E. Myers, J. Soberón, N. Barve, C. M. Hensz, A. T. Peterson, H. L. Owens, And A. LiRA-Noriega. 2012. Variation in niche and distribution model performance: The need for a priori assessment of key causal factors. Ecological Modelling 237-238:11-22.

Simpson, G. G. 1950. History of the fauna of Latin America. American Scientist, 38: 361-389.

Soberón, J., AND M. NaKamURA. 2009. Niches and distributional areas: concepts, methods, and assumptions. Proceedings of the National Academy of Sciences, 106(Supplement 2):19644-19650.

Solari, S., Y. Muñoz-Saba, J. V. Rodríguez-Mahecha, T. R. Deffler, H. E. Ramírez-Chaves, and F. Trujlllo. 2013. Riqueza, endemismo y conservación de los mamíferos de Colombia. Mastozoología Neotropical 20:301-365.

Spradling T. A., J. W. Demastes, D. J. Hafner, P. L. Milbach, F. A. Cervantes, And M. S. Hafner. 2016. Systematic revision of the pocket gopher genus Orthogeomys. Journal of Mammalogy 97:405-423.

SUdman, P. D., AND M. S. HAFner. 1992. Phylogenetic relationships among Middle American pocket gophers (genus Orthogeomys) based on mtDNA sequences. Molecular Phylogenetics and Evolution 1:17-25.

Thuiller, W., S. Lavorel, AND M. B. Araujo. 2005. Niche properties and geographical extent as predictors of species sensitivity to climate change. Global Ecology and Biogeography 14:347-357.

TIRIRA, D. G. 2010. Mamíferos de los bosques húmedos del noroccidente de Ecuador. Ediciones Murciélago Blanco y Proyecto PRIMENET. Publicación Especial 7. Quito, Ecuador.

Tocchio, L. J., R. Gurgel-Gonçalves, L. E. Escobar, And A. T. Peterson. 2015. Niche similarities among white-eared opossums (Mammalia, Didelphidae): is ecological niche modelling relevant to setting species limits. Zoologica Scripta 44:1-10.

VALDÉs-VELÁSQUEZ, A. 2003. Taxonomy, phylogeny and biogeography of the hummingbird genus Thalurania Gould, 1848 (Aves: Trochilidae). Doctoral dissertation, PhDThesis, Alexander Koenig Research Institute and Museum of Zoology (ZFMK), Rheinische Friedrich-Wilhelms Universität, Bonn.

Wiens, J. J., AND C. H. GRaham. 2005. Niche Conservatism: Integrating Evolution, Ecology, and Conservation Biology. Annual Review of Ecology, Evolution and Systematics 36:519-539.

Woodman, N., and J. Pefaur. 2008. Order Soricomorpha Gregory, 1910. Pp. 177-187, in Mammals of South America. Volume 1. Marsupials, Xenarthrans, Shrews, and Bats (Gardner, A. L., ed.). The University of Chicago Press. Chicago, U. S. A.

Associated editor: Guillermo D'Elia

Submitted: July 4, 2017; Reviewed: October 1, 2017;

Accepted:September 20, 2017; Published on line:September 30, 2017. 
ORTHOGEOMYS (GEOMYIDAE) FROM CHOCÓ.

240 THERYA Vol. 8 (3): 233-240 